these catalogues form the medium for the first announcement of bibliographical discoveries of importance. A case in point is afforded by a catalogue (No. 73) recently issued by Messrs. Davis and Orioli, of 37 Museum Street, London, W.C.1. In this list, there is offered for sale a book that the vendors claim to be the hitherto undescribed first printed text of Petrus Peregrinus's treatise "De Magnete". The book in question, a small quarto of six leaves, is entitled "De Virtute Magnetis", and its title page bears the name of Raymundus Lullus as author; but no date or place of printing is indicated. The text is almost identical with that of the edition of Peregrinus's treatise published at Augsburg in 1558, hitherto regarded by bibliographers as the first printed edition. The original "Epistola De Magnete" was written in the thirteenth century, probably in 1269, and several early MSS. copies exist. In a long and interesting note, Messrs. Davis and Orioli give reasons for believing the book they describe to have been printed at Rome by E. M. Silber, not later than the year 1520 . They state that, in the past, Peregrinus's treatise has been ascribed both to Raymond Lull and to Roger Bacon, and it is suggested that these authors' names may have been used in a general way during the Renaissance as possible authors of any scientific works. While the 1558 edition is a book of extreme rarity, Messrs. Davis and Orioli have so far only been able to trace one other copy of "De Virtute Magnetis", that in the Bibliothèque Nationale, Paris.

\section{South African Marine Fishes}

IN a recent descriptive account of "The South African Marine Fishes of Commercial and Angling Importance" by J. M. Marchand (Dept. of Commerce and Industries: Fishery Bulletin No. 2), an attempt is made to provide a handbook for the convenience and use of persons interested in South African sea fishes from the commercial point of view, for sportsmen, and for teachers of biology in South African schools. It is pointed out in the introduction to this work that it is "not intended for the pure scientist, and will be of small if any value to such individuals, due to the limited number of species dealt with, the total lack of classification keys and the brevity of the descriptions". Owing to the brevity of the descriptions, much reliance will have to be placed on the photographic illustrations in making identifications of fishes not already known. This is most unfortunate, for the great majority are so lacking in detail as to be almost useless for this or any other purpose. Some of them, for example, the photograph of Raia clavata on p. 52 and of Arnoglossus pectoralis on p. 67, are little more than dark blotches on the paper. When, for any reason, detailed drawings cannot be used, simple but accurate outline sketches are infinitely preferable to poorly reproduced photographs for the illustration of a handbook of this kind.

\section{Indian Industrial Publications}

THE Indian Industrial Research Bureau has issued a bibliography of industrial publications published in India since 1921 (Bulletins of Indian Industrial Research. No. 1: Bibliography of Industrial Publications published in India from 1921. Pp. iii +257. Delhi : Manager of Publications, 1936. 4.6 rupees ; 7s. $3 d$.). The first part consists of a list of papers arranged chronologically according to publications, which enables readers readily to ascertain the papers published by each local government, government department, society, etc. Publications available in the Library of the Industrial Research Bureau are indicated. The second part is a classified subject bibliography arranged according to the Universal Decimal Classification. The third section of the bibliography comprises a combined alphabetical author and subject index.

\section{Natural History Magazine}

ThE October number of this British Museurn publication contains an interesting account of the remounting and preservation of the famous Cranbourne meteorite, the conclusion of a long description of the Museum's East African Expedition, and a paper on vermin, based upon Steele Elliot's Bedfordshire records. We record with regret the concluding paragraph of the number : "The Trustees of the British Museum have decided to cease the publication of the Natural History Magazine after the issue of the present number, which completes the fifth volume". The experiment has not been long-lived, and as members of the reading public we should attribute its failure to the price charged for what is essentially Museum advertisement and propaganda, and to the tendency of contribators to forget that lightness of hand as well as solid fact is a necessary ingredient in attractive writing.

\section{Index to the Geographical Review}

THe Geographical Review (the quarterly journal of the American Geographical Society) for the ten-year period from 1926 to 1935 contains 7,000 pages of articles, record items, and book reviews, including more than fifty articles on the geographical results of important expeditions, most of them written by the expedition leaders themselves. To make this great mass of geographical material available in organized form, the Society has now prepared an analytical index of 373 pages covering this ten-year period. The price of the index is : unbound, 4.50 dollars ; bound, 5.25 dollars. The index to vols. 1-15, 1916-25, of which there are still a limited number of copies available, is offered along with the index to vols. 16-25, at a special price of 8.00 dollars unbound, or 9.50 dollars bound, for the two indexes. These may be obtained from the American Geographical Society, Broadway at 156th Street, New York, N.Y.

\section{Medical Peace Association}

A MEETING of medical practitioners and other scientific workers to consider the subject of aerial warfare and means of defence against it will be held in the Hastings Hall, British Medical House, on Wednesday, November 25 , at 8.30 p.m. The chair will be taken by Dr. E. P. Poulton, and speakers 
will include Dr. Stella Churchill, Dr. Robert Edbrooke, Mr. R. Makinnon Wood and Dr. L. A. Rawlings. It is hoped that there will be a full discussion of the whole subject, and particularly of the attitude which the medical profession might reasonably adopt towards it. Information about the Medical Peace Association may be obtained from the Hon. Secretary, Dr. Cecile Booysen, 12 Kent Terrace, N.W.1.

\section{Nutrition in the Colonial Empire}

THE Prime Minister has appointed a Committeo of the Economic Advisory Council with the following terms of reference: "(1) To survey the present state of knowledge in regard to nutrition in the Colonial Empire in the light of the replies received to the circular dispatch addressed by the Secretary of State for the Colonies on April 18, 1936, to the Officers Administering the Governments of Colonial Dependencies. (2) To advise from time to time as to the measures calculated to promote the discovery and application of knowledge in this field." The Committee is constituted as follows : Earl De La Warr (chairman), Prof. E. P. Cathcart, Mr. G. L. M. Clauson, Dr. Philippa C. Esdaile, Prof. Noel Hall, Dr. J. M. Hamill, Mr. Francis Hemming, Mr. E. M. H. Lloyd, Prof. Edward Mellanby, Sir John Orr, Dr. Audrey Richards, Mr. H. S. Scott, Sir Thomas Stanton, Mr. F. A. Stockdale, Mr. Hans Vischer. The secretaries to the Committee are Mr. D. H. F. Rickett (Economic Advisory Council) and Mr. C. G. Eastwood (Colonial Office).

\section{Announcements}

Mme. JoLIot-CURre has resigned her appointment of Under-Secretary for Scientific Investigation in the French Cabinet to occupy a chair in the Faculty of Natural Science at the Sorbonne, and has been succeeded by Prof. M. Jean Perrin, For.Mem.R.S., known for his work on atomic chemistry, and Nobel prizeman for physics in 1926.

Dr. Wolfand Heubner, professor of pharmacology at the University of Berlin, has been elected an honorary member of the Biological Society of Vienna and of the Imperial Leopold Caroline German Academy of Natural Philosophers at Halle.

Prof. Ferdinand Hueppe, of Dresden, emeritus professor of hygiene in the German University at Prague, has been awarded the Goethe Medal for Science and Art by the Chancellor of the Reich in recognition of his services in connexion with physical training.

AT the thirty-ninth Congress of the International Law Association for the Protection of the Civilian Population against Modern Warfare, recently held in the Cour de Cassation of the Paris Palais de Justice, a committee was formed to consider the question of the protection of the civilian population against the new engines of warfare, and especially aerial bombardment. The work of the Committee will be carried on in close association with the International Committee of the Red Cross and the International Association for the Protection of Humanity recently founded at Monaco.

Advisory Leaflet No. 272 of the Ministry of Agriculture directs attention to the disease fowl paralysis, which is unfortunately becoming more common. The cause is not known, and no treatment of proved value is available, but the disease can be minimized by removing weak birds, and by not breeding from infected stocks.

Cultivation and distillation of peppermint form the subject of Advisory Leaflet No. $\mathbf{9 8}$ of the Ministry of Agriculture. Two varieties of this fragrant herb are recognized, namely, black mint, Mentha piperata var. officinalis, and white mint, $M$. piperata var. vulgaris. Harvesting and distilling are described in detail, and the effects of the fungus disease, Puccinia menthce, are considered. Peppermint might be grown with advantage on a larger scale in Great Britain.

THE resumption of work in the technicel schools and eolleges gives special value to the issue of Foyle's Technical Catalogue (London: W. and G. Foyle, Ltd.) which contains particulars of new and second-hand books on more than 450 subjects coming within the range of applied science.

THE latest catalogue of old scientific books issued by E. P. Goldschmidt and Co., Ltd., of Bond Street, W.1 (No. 40. Old Science and Medicine) includes 216 items, many of great interest, on a variety of subjects, and contains a number of facsimile and other illustra. tions. Among the books offered for sale are copies of the first edition of Gilbert's "De Magnete", and of an edition of this work printed at Stettin in 1633.

Applications are invited for the following appointments, on or before the dates mentioned :

Assistants, Grade II and III (engineering) in the Admiralty Technical Pool-The Secretary of the Admiralty (C.E. Branch), Whitehall, London, S.W.1 (November 2).

A heating and ventilating engineer in the Directorate of Works and Buildings of the Air MinistryThe Secretary (W.B. 9), Air Ministry, Adastral House, Kingsway, W.C.2 (November 14).

A research assistant in the Department of Oil Engineering and Refining, University of Birmingham -The Secretary (November 18).

A junior lecturer in civil engineering in the Uni. versity of the Witwatersrand-The Secretary, Office of the High Commissioner for the Union of South Africa, South Africa House, Trafalgar Square, London, W.C.2 (December 2).

Structural engineering assistants in the Designs Branch of the Directorate of Fortifications and Works at the War Office-The Under-Secretary of State (C.5), The War Office, London, S.W.1 (Quote Appts. (2).

An acting editor to the Royal Scottish Geographical Society-The Secretary, Synod Hall, Edinburgh. 